\title{
Comparison of an ultra-low volume (ULV) sprayer against a conventional sprayer, for foliar fertiliser and fungicide applications in turfgrass
}

\author{
Jason Connor Ferguson ${ }^{1 *}$, Roch E. Gaussoin ${ }^{1}$, John A. Eastin ${ }^{2}$, \\ Matthew D. Sousek ${ }^{1}$, Greg R. Kruger ${ }^{3}$ \\ ${ }^{1}$ Department of Agronomy and Horticulture, University of Nebraska-Lincoln, Lincoln, 68583, NE, USA \\ ${ }^{2}$ Kamterter Products LLC, 9930 N 134th Street, Waverly, 68462, NE, USA \\ ${ }^{3}$ University of Nebraska-Lincoln, North Platte, 402 W. State Farm Road, North Platte, 69101, NE, USA
}

Received: September 28, 2015

Accepted: February 14, 2016

\begin{abstract}
Two field studies (I and II) at the University of Nebraska-Lincoln: John Seaton Anderson Turfgrass Research Facility near Mead, NE, USA, were conducted to determine if a new ultra-low volume (ULV) sprayer can apply foliar nutrient, growth regulator, and fungicide treatments, in a manner similar to that of a conventional sprayer. Treatments were applied over creeping bentgrass 'L-93' (Agrostis stolonifera L.) managed as a fairway at $5611 \cdot$ ha $^{-1}$ and $471 \cdot$ ha $^{-1}$ with the conventional and ULV sprayer, respectfully. Data were collected for chlorophyll content with a chlorophyll meter, and for the normalised difference vegetation index (NDVI) with a turf colour meter. Each plot was harvested for biomass at 21 days after treatment. Study II compared the ULV sprayer and a conventional sprayer, for the control of brown patch (Rhizoctonia solani Kuhn) in creeping bentgrass. The treatments were propiconazole and azoxystrobin. Spray volume was $561 \mathrm{l} \cdot \mathrm{ha}^{-1}$ for the conventional sprayer, and $191 \cdot \mathrm{ha}^{-1}$ for the ULV sprayer. Statistical differences in turf quality or dry weight reductions between the conventional and ULV sprayer were not detected. Brown patch control was also similar between the two sprayers, but azoxystrobin provided better control than propiconazole. Even with a 30-fold decrease in application volume, the results indicated that the Kamterter ULV sprayer may be a useful and effective management option for foliar fertiliser and fungicide applications in turfgrass.
\end{abstract}

Key words: application carrier volume, fertiliser application, Rhizoctonia solani, turfgrass management, ULV sprayer

\section{Introduction}

Turfgrass protection product labels commonly recommend a carrier volume of at least $187 \mathrm{l} \cdot \mathrm{ha}^{-1}$ to deliver acceptable efficacy of the product (Anonymous 2008a, b, 2009, 2010, 2012). Previous research with turfgrass protection products analysed alternative methods of spray applications, but the convention is to use application volumes of $1871 \cdot$ ha $^{-1}$ or greater (Bhowmik and Bingham 1990; Johnson 1993a, b; Johnson 1997). Couch (1985) reported carrier volumes of at least $407 \mathrm{l} \cdot \mathrm{ha}^{-1}$ with contact fungicides and $814 \mathrm{l} \cdot \mathrm{ha}^{-1}$ for systemic fungicides to achieve acceptable control of brown patch (Rhizoctonia solani Kuhn) and other diseases in turf management. Other research has demonstrated that an application volume of at least $407 \mathrm{l} \cdot \mathrm{ha}^{-1}$ was necessary for proper disease suppression in turfgrass (Fidanza 2009; Fidanza et al. 2009). This results in a reduced application efficiency because applicators and golf course superintendents can only cover a limited area per tank load. The use of ultra-low volume (ULV) technology has been documented in other cropping systems (Bode et al. 1985) but is not widely in use with turfgrass.
Creeping bentgrassis is a common cool-season turfgrass in Nebraska and Midwest, USA. It is used primarily on golf courses and other highly managed playing surfaces. Golf greens are intensively managed turfgrass systems requiring an annual nitrogen application of 100 to $250 \mathrm{~kg} \cdot \mathrm{ha}^{-1}$ per growing season (Carrow et al. 2001). Recent studies have identified the benefits of using foliar nutrients to enhance turf growth and quality, especially in creeping bentgrass (Gaussoin et al. 2009; Stiegler et al. 2011). Golf course superintendents and turf managers apply nitrogen and other micronutrients as part of their management program to improve turf growth. Trinexapac-ethyl use on turfgrass has led to increased nitrogen use efficiency and to drought tolerance during the summer months (Goss et al. 2002; McCann and Huang 2007; Kreuser and Soldat 2012). Trinexapac-ethyl use has also demonstrated an increase in turf quality by reducing plant stress (Heckman et al. 2001; McCullough et al. 2007).

Brown patch is a common disease, during hot and humid conditions, of creeping bentgrass which can be serious if not treated (Martin and Lucas 1984). The pathogen primarily affects the plant tissues at or above the soil surface (Burpee and Martin 1992). Fungicide applications on 
creeping bentgrass greens are regularly made to prevent and suppress brown patch from June to September in Midwest, USA (Settle et al. 2001). Golf course superintendents commonly make applications every 14 to 21 days during months where hot and humid weather persists (Settle et al. 2001). Azoxystrobin is a common strobilurin fungicide for the control of brown patch in creeping bentgrass and other turfgrasses. It inhibits fungal pathogens by interfering with cellular respiration through the disruption of electron transport in the mitochondria (Aspinall and Worthington 1999). Propiconazole is another widely used systemic fungicide for brown patch control in creeping bentgrass. Propiconazole is a dimethylation inhibitor that was first approved for use in turfgrass in the early 1980's (Martin 2003).

Kamterter LLC in Waverly, NE, has developed the ULV sprayer to deliver application volumes as low as $91 \cdot \mathrm{ha}^{-1}$. The sprayer utilises twin fluid atomisation principles that combine two precisely metered low pressure fluids, air and a liquid, to spray fixtures for atomisation and spray pattern control. In-depth discussions of the mechanics of the sprayer are found in Eastin and Vu (2012), and Ferguson et al. (2014a, b). The fixtures of the ULV sprayer have a larger orifice than conventional nozzles, this allows for products to be applied that are not feasible with conventional pressure-against-an-orifice nozzles (Hanks and McWhorter 1991). The objective of these studies was to assess whether the ULV sprayer can effectively apply foliar fertilisers or fungicides in a turfgrass system, with effects comparable to a conventional sprayer.

\section{Materials and Methods}

\section{Description of treatments and research site}

The research was conducted at the University of NebraskaLincoln: John Seaton Anderson Turfgrass Research Facility near Mead, NE, USA. We evaluated an ULV sprayer against a conventional sprayer (Toro Multi-Pro 1200, The Toro Company, Bloomington, MN, USA, 55420). Treatments with the conventional sprayer were always applied at $5611 \cdot$ ha $^{-1}$ with flat-fan XR11006VS nozzles (Spraying Systems Co., Wheaton, IL, USA, 60187) at $310 \mathrm{kPa}$ and a ground speed of $5 \mathrm{~km} \cdot \mathrm{h}^{-1}$. The ULV sprayer treatments were applied at $191 \cdot \mathrm{ha}^{-1}$ in study II, and $471 \cdot \mathrm{ha}^{-1}$ in study I, with operating parameters of atmospheric pressure for the liquid and $5 \mathrm{kPa}$ for the air pressure at the spray fixtures and at a ground speed of $5 \mathrm{~km} \cdot \mathrm{h}^{-1}$. The conventional sprayer nozzles and ULV fixtures were all spaced at $50 \mathrm{~cm}$ and both sprayers had boom heights of $50 \mathrm{~cm}$ above the turf. The trials were applied over creeping bentgrass 'L-93' managed at a fairway height of $1.3 \mathrm{~cm}$. The soil type at the site was a Tomek silty clay loam (fine, montmorillonitic, mesic Typic Argiudoll). Treatments in each study were arranged in a randomised complete block design with $1.5 \times 3 \mathrm{~m}$ plot sizes. In each year of replication, the trials were not conducted over the previous plot locations.

\section{Study I}

The study contained three treatments for each sprayer and an untreated check (seven total treatments) arranged in a randomised complete block design with three replications. The treatments were: trinexapac-ethyl alone (T-NEX $1^{\circledR}$ AQ Quali-Pro, Raleigh, NC, USA, 27609) applied at $96 \mathrm{~g}$ a.i., a [13-2-3-0.12-1.4-0.2-0.2] [N-P-K-Cu-FeMn-Zn](Gary's Green Ultra ${ }^{\circledR}$, Grigg Brothers, Albion, ID, USA, 83311) applied at 29 product $\cdot \mathrm{ha}^{-1}+\mathrm{a}$ [3-7-18-0.020.01-0.05-0.001][N-P-K-B-Co-Cu-Mo] (P-K Plus ${ }^{\circledR}$, Grigg Brothers, Albion, ID, USA, 83311) applied at 191 product . - $\mathrm{ha}^{-1}$, and a treatment containing all three products at the respective rates mentioned above. Application carrier volume with the ULV sprayer was $47 \mathrm{l} \cdot \mathrm{ha}^{-1}$ which was increased to keep the product application rates equal between the two sprayers. The tank mix treatments containing the foliar fertilisers with the ULV sprayer were mixed without any dilution and consequently were applied as pure product due to the low carrier volume feature of the ULV sprayer. The turf was watered daily to replace $80 \%$ ET and mowed every other day until the end of the first week of the study. A chlorophyll meter (FieldScout CM 1000 NDVI Chlorophyll Meter, Spectrum Technologies Inc. Plainfield, IL, USA, 60585) was used to take three measurements of chlorophyll content in each plot at 7 and 14 days after treatment (DAT) in 2012 and 21 DAT in 2011. Three measurements in each plot were obtained for the normalised difference vegetation index (NDVI) with a turf colour meter (FieldScout TCM 500 NDVI Turf Color Meter' Spectrum Technologies Inc. Plainfield, IL, USA, 60585). Plots were mowed after the first week and then left unmowed until they were harvested for a clipping biomass at 21 DAT. The clipping biomass was obtained by mowing a strip in the centre of each plot measuring $0.6 \times 3 \mathrm{~m}$ and collecting those clippings from each plot. The clippings were dried for $48 \mathrm{~h}$ at $60^{\circ} \mathrm{C}$ and dry weights were recorded. Weather data for the spraying and harvesting are listed in table 1.

\section{Study II}

The study contained two treatments for each sprayer and an untreated check arranged in a randomised complete block design with four replications. Treatments selected were propiconazole (Banner Maxx II ${ }^{\circledR}$, Syngenta Crop Protection, Greensboro, NC, USA, 27419) applied at $1,747 \mathrm{~g}$ a.i. $\cdot$ ha $^{-1}$ and azoxystrobin-methyl (Heritage $\mathrm{TL}^{\circledR}$, Syngenta Crop Protection, Greensboro, NC, USA, 27419) applied at $538 \mathrm{~g}$ a.i. $\cdot$ ha $^{-1}$. Treatments were applied on June 28, 2012 and August 2, 2012. In 2013, treatments were applied on July 7 and August 8, respectively. The creeping bentgrass was managed at a fairway height of $1.3 \mathrm{~cm}$ for the study. Plots were mowed every other day. The turf was watered daily to replace $80 \%$ ET. Plots were rated for visual estimations of brown patch at 14, 28,7/35, and 28/56 DAT. The DAT timings with multiple values are the days after the second application/the days after the first application, respectively.

\section{Statistical analyses}

Study II data were analysed with a repeated measures analysis using a general linear mixed model (PROC GLIMMIX) with replication as the random variable, and 
Table 1. The 2011 and 2012 weather conditions at the John Seaton Anderson Turf Research Facility near Mead, NE, USA, during the foliar fertiliser trial

\begin{tabular}{lcccc}
\hline \multirow{2}{*}{ Conditions } & \multicolumn{4}{c}{ Date and event } \\
\cline { 2 - 5 } & $9 / 15 / 2011$ & $10 / 06 / 2011$ & $06 / 28 / 2012$ & $07 / 19 / 2012$ \\
\cline { 2 - 5 } & application & harvest & application & harvest \\
\hline High temperature & $17.2^{\circ} \mathrm{C}$ & $28.8^{\circ} \mathrm{C}$ & $38.9^{\circ} \mathrm{C}$ & $38.3^{\circ} \mathrm{C}$ \\
Low temperature & $3.3^{\circ} \mathrm{C}$ & $13.8^{\circ} \mathrm{C}$ & $22.7^{\circ} \mathrm{C}$ & $21.7^{\circ} \mathrm{C}$ \\
Dew point & $1.3^{\circ} \mathrm{C}$ & $6.8^{\circ} \mathrm{C}$ & $22.7^{\circ} \mathrm{C}$ & $20^{\circ} \mathrm{C}$ \\
Wind speed/direction & $10.3 / \mathrm{NW}$ & $30.6 / \mathrm{SW}$ & $9.8 / \mathrm{W}$ & $9.3 / \mathrm{W}$ \\
\hline Precipitation & & $16 \mathrm{~mm}^{*}$ & & $0 \mathrm{~mm}$ \\
\hline
\end{tabular}

Conditions for the two years of the research are compiled for the date of application and the biomass harvest at 21 days after treatment. Wind speed is expressed as the average wind speed in kilometers per hour. Precipitation is the sum total during the three week period for each year of the study.

*the precipitation from 2011 occurred only in the 5 days following the application

the sprayer type, and date of measurement and treatment as the fixed variables. Study I data were analysed with a general linear mixed model, with replication as the random variable, and the sprayer type, date of measurement and treatment as the fixed variables. For both studies, the mean separations were made with Tukey's HSD (Kramer 1957) at $\alpha=0.05$. For study II, year was not significant, so the data were analysed across both years. The data were analysed in SAS (Statistical Analysis System) software. Version 9.2. SAS Institute, Inc., Box 8000, SAS Circle, Cary, NC, USA, 27513).

\section{Results}

\section{Study I}

There were no differences across any of the recorded variables due to sprayer type. Differences in date of measurement in 2012 were observed in the chlorophyll content and NDVI data where the 14 DAT measurement showed improved turf quality (Table 2). Turf quality improved across all treatments, including the untreated plots. Normalised difference vegetation index values increased across plots from 7 to 14 DAT on those plots that had received a fertiliser application. This result was not observed in the plots that were treated with trinexapac-ethyl alone. In 2011, there were no differences in turf quality. The temperature conditions for both years were different $(p<0.001)$, so the years were analysed separately.

\section{Study II}

Treatment differences were observed across both years $(\mathrm{p}<0.001)$ where azoxystrobin reduced brown patch severity more than propiconazole. Both sprayer types resulted in a similar reduction of brown patch with either of the studied fungicides. Date of measurement differences were also observed $(p<0.001)$ where visual estimations of brown patch were lower after the second application of fungicides compared to after the first application

Table 2. The effect of foliar treatments on chlorophyll content, NDVI reflectance percentage, and dry weights, on a creeping bentgrass fairway, from the two sprayers, in 2011 and 2012

\begin{tabular}{|c|c|c|c|c|c|c|c|c|c|}
\hline \multirow{4}{*}{ Treatment } & \multirow{4}{*}{$\begin{array}{l}\text { Product } \\
\text { rate } \\
{\left[1 \cdot \mathrm{ha}^{-1}\right]}\end{array}$} & \multicolumn{3}{|c|}{ Chlorophyll content } & \multicolumn{3}{|c|}{ NDVI } & \multicolumn{2}{|c|}{ Dry weights } \\
\hline & & 2011 & & & 2011 & & & 2011 & 2012 \\
\hline & & \multicolumn{3}{|c|}{ [relative chlorophyll content] } & \multicolumn{3}{|c|}{ [\% reflectance] } & \multicolumn{2}{|c|}{$\left[\mathrm{g} \cdot\right.$ plot $\left.^{-1}\right]$} \\
\hline & & 21 DAT & $7 \mathrm{DAT}$ & $14 \mathrm{DAT}$ & $21 \mathrm{DAT}$ & $7 \mathrm{DAT}$ & $14 \mathrm{DAT}$ & - & - \\
\hline Untreated & - & 414 & $322 \mathrm{~b}$ & $388 \mathrm{a}$ & 81 & $74 \mathrm{bc}$ & $77 \mathrm{a}$ & 24 & 65 \\
\hline Trinexapac-ethyl & 1 & 418 & $341 \mathrm{~b}$ & 397 a & 80 & $76 \mathrm{ab}$ & $76 \mathrm{ab}$ & 20 & 69 \\
\hline $\begin{array}{l}\text { N-P-K-Cu-Fe-Mn- } \\
\text { Zn fertiliser blend + } \\
\text { N-P-K-B-Co-Cu-Mo } \\
\text { fertiliser blend }\end{array}$ & $29+19$ & 454 & $319 b$ & 409 a & 81 & $73 \mathrm{bc}$ & $76 \mathrm{a}$ & 29 & 65 \\
\hline $\begin{array}{l}\text { Trinexapac-ethyl + } \\
\text { N-P-K-Cu-Fe-Mn- } \\
\text { Zn fertiliser blend + } \\
\text { N-P-K-B-Co-Cu-Mo } \\
\text { fertiliser blend }\end{array}$ & $1+29+19$ & 423 & $315 b$ & 383 a & 79 & $73 c$ & 77 a & 19 & 62 \\
\hline
\end{tabular}

Timing differences were noted in the chlorophyll content and normalized difference vegetation index (NDVI) percentage in 2012. There were no statistical differences between sprayer type in both years of the study. Chlorophyll content and NDVI were analysed as a repeated measures analysis and the 2011 data and the dry weight data were analysed with a generalised linear mixed model. Results with the same letter indicate no statistical difference. 
Table 3. Brown patch infection on a creeping bentgrass fairway, when treated with propiconazole and azoxystrobin from a conventional and ULV sprayer

\begin{tabular}{lccccc}
\hline \multirow{2}{*}{ Treatment } & \multirow{2}{*}{$\begin{array}{c}\text { Rate } \\
{\left[\mathrm{g} \mathrm{a.i.} \cdot \mathrm{ha}^{-1}\right]}\end{array}$} & \multicolumn{4}{c}{$\begin{array}{c}\text { Brown patch } \\
{[\%]}\end{array}$} \\
\cline { 3 - 6 } & - & $14 \mathrm{DAT}$ & $28 \mathrm{DAT}$ & $7 / 35 \mathrm{DAT}^{*}$ & 28/56 DAT $^{*}$ \\
\hline Untreated & 1,747 & $53 \mathrm{~d}$ & $38 \mathrm{de}$ & $5 \mathrm{ab}$ & $0 \mathrm{a}$ \\
Propiconazole & 538 & $31 \mathrm{c}$ & $48 \mathrm{~d}$ & $0 \mathrm{a}$ & $0 \mathrm{a}$ \\
Azoxystrobin & $18 \mathrm{a}$ & $7 \mathrm{ab}$ & $1 \mathrm{a}$ & $0 \mathrm{a}$ \\
\hline
\end{tabular}

Treatments with the same letters were not statistically different. The ratings were separated through a repeated measurement analysis. Treatments were grouped across sprayer types as there was no difference between them.

*the $7 / 35$ and 28/56 days after treatment ratings represent 7 and 28 days after the second application and 35 and 56 days after the first application respectively

(Table 3). The second application of propiconazole or the second application of azoxystrobin, further reduced brown patch severity. Between the 35 and 56 DAT measurement, the weather was noticeably cooler, which further reduced brown patch toward the end of the study in 2012. This was also observed in the untreated plots where the brown patch severity continued to decrease throughout the study (Table 3).

\section{Discussion}

\section{Study I}

The trial was replicated over two years and applied in different meteorological conditions to exacerbate differences that might exist between the two sprayers. The trial was first applied on September 15, 2011 during a very cool and damp three weeks in the autumn. The trial was replicated in 2012 and sprayed on June 28, 2012, in order to conduct the study in hotter and drier conditions. The summer of 2012, in Nebraska, was one of the hottest and driest on record which allowed for a true range of conditions with which to compare the two sprayers in this study (Table 1). Since creeping bentgrass is very sensitive, the hot and dry conditions were ideal for observing turf burn from the treatments. Over both years there was no observed turf burn from treatments applied from either sprayer - even pure product treatments applied from the ULV sprayer.

The foliar nutrient additions improved turf quality with both sprayers at 14 DAT. There was an increase in the NDVI values from the 7 DAT to the 14 DAT measurements in plots that received a fertiliser treatment. This result signified a positive effect of the application on turf quality. The chlorophyll content improved across all treatments, but showed the largest gains in plots that received a treatment containing a fertiliser component. The dry weight harvests of each plot did not reveal a perceived benefit with the fertiliser addition where improved turf quality did not lead to increased turf biomass. A reduction in biomass compared to the untreated was observed in the combination treatment of fertiliser + trinexapacethyl. But the trinexapac ethyl treatment used alone, resulted in an increased biomass. None of the biomass results were statistically different.
The conditions were quite different in both years of the study as referenced in table 2, yet the hot and dry summer of 2012 did not produce a different result from the cooler autumn application in 2011. Uptake of nutrients was greater in the autumn 2011 application as compared to the summer 2012 application, which confirms the findings from Gaussoin et al. (2009). In their study, they implemented a similar fertilisation scheme and found reduced nutrient uptake from a summer application. The application of trinexapac-ethyl used alone, did not reduce the dry weight biomass harvested from each plot as compared to the untreated plots, across both years of the study. Reduced dry weights, though, were observed in the combination treatment of fertiliser + trinexapac-ethyl. Trinexapac-ethyl did not appear to enhance turf quality in either year as chlorophyll and NDVI values were similar to the values of the untreated plots, however, leaf tissues were not analysed to quantify differences.

\section{Study II}

The ULV sprayer at $191 \cdot$ ha $^{-1}$ reduced brown patch severity similar to the conventional sprayer at $5611 \cdot \mathrm{ha}^{-1}$; a 30fold reduction in application carrier volume. Brown patch was suppressed with an application carrier volume lower than that which Couch (1985) and Fidanza et al. (2009) identified as necessary for disease management with systemic fungicides. Azoxystrobin was not evaluated in the Couch (1985) study as azoxystrobin was not released until 1996, eleven years after his research was conducted. Propiconazole, however, was included in the Couch (1985) study, and the results from this study suggest that application carrier volume could be reduced without loss in efficacy. Further research is required to determine if the $814 \mathrm{l} \cdot \mathrm{ha}^{-1}$ application carrier volume used in that study would have provided greater brown patch control versus the $5611 \cdot$ ha $^{-1}$ application carrier volume with a conventional sprayer or the $191 \cdot \mathrm{ha}^{-1}$ application carrier volume with the ULV sprayer from this study. Previous research dealing with herbicides on weed control, showed that efficacy of contact herbicides was not affected by lower application carrier volumes with the ULV sprayer (Ferguson et al. 2014b).

The droplet size spectrum of the ULV sprayer fixtures has been compared in previous studies (Ferguson et al. 2014a, b). The ULV sprayer produced a similar droplet 
size to the trialled hydraulic nozzles, which in both studies were XR 11003 nozzles. Previous research with the ULV sprayer also showed a larger overall droplet size with the ULV sprayer fixtures compared to XR nozzles, when a drift reduction adjuvant was added to the spray solution. The nozzles used in this study were XR 11006 nozzles, which likely would have produced a larger droplet size than the ULV sprayer fixtures, but this difference appears to be negligible based on the efficacy results from this study.

\section{Conclusions}

Results from this study and previous research, demonstrate the effectiveness of the ULV sprayer in turfgrass. Given the ability to make turfgrass protection and fungicide applications at a thirty-fold decrease in application carrier volume, means a greatly improved efficiency of application for golf-course superintendents and turf managers. The ULV sprayer provides an application system comparable to conventional application technology in turfgrass, across a wide range of products and management types in turfgrass.

\section{References}

Anonymous. 2008a. Gary's Green Ultra ${ }^{\mathrm{TM}}$ foliar nutrient label. Albion, ID: Grigg Bros. 1 p. Available on: http://www. griggbros.com/attachments/200-GarysGreenUltra.pdf [Accessed: August 12, 2015]

Anonymous. 2008b. P-K Plus ${ }^{\mathrm{TM}}$ foliar nutrient label. Albion, ID: Grigg Bros. 1 p. Available on: http://www.griggbros.com/ attachments/285-PKPlus.pdf [Accessed: August 12, 2015]

Anonymous. 2009. Banner Maxx ${ }^{\circledR}$ II fungicide label. Greensboro, NC: Syngenta Crop Protection Inc. 21 p. Available on: http://www.cdms.net/LDat/ld99L000.pdf [Accessed: August 12, 2015]

Anonymous. 2010. Heritage ${ }^{\circledR}$ TL fungicide label. Greensboro, NC: Syngenta Crop Protection Inc. 20 p. Available on: http://www.cdms.net/LDat/ld6NG006.pdf [Accessed: August 12, 2015]

Anonymous. 2012. T-NEX ${ }^{\circledR} 1 \mathrm{AQ}$ herbicide label. Raleigh, NC: MakhteshimAgan North America Inc. 15 p. Available on: http://fs1.agrian.com/pdfs/T-NEX_1AQ_Label2.pdf [Accessed: August 12, 2015]

Aspinall I.H., Worthington P.A. 1999. $\beta$-Methoxyacrylates; synthesis of new types of strobilurin fungicides with extended side chains. Pesticide Science 55 (2): 197-198.

Bhowmik P.C., Bingham S.W. 1990. Preemergence activity of dinitroaniline herbicides used for weed control in cool-season turfgrasses. Weed Technology 4 (2): 387-393.

Bode L.E., Butler B.J., Wax L.M. 1985. Use of electrostatics, rotary atomizers, and vegetable oils in low-volume ground application. ASTM Special Technical Publication 875: 78-87.

Burpee L.L., Martin B. 1992. Biology of Rhizoctonia species associated with turfgrasses. Plant Diseases 76: 112-117.

Carrow R.N., Waddington D.V., Rieke P.E. 2001. Turfgrass Soil Fertility and Chemical Problems: Assessment and Management. John Wiley \& Sons, Inc., Hoboken, New Jersey, USA, 387 pp.
Couch H.B. 1985. Turfgrass fungicides II: Dilution rates, nozzle size, nozzle pressure and disease control. Golf Course Management 52: 73-76, 78-80.

Eastin J.A., Vu D. 2012. U.S. Patent 8,091,272 B2: Systems for the control and use of fluids and particles. U.S. Patent Office.

Ferguson J.C., Gaussoin R.E., Eastin J.A., Henry R.S., Kruger G.R. 2014a. Effect of application carrier volume on a conventional sprayer system and an ultra-low volume sprayer. Pesticide Formulation and Delivery Systems. Vol. 33. "Sustainability: Contributions from Formulation Technology". STP 1569, Carmine Sesa, ASTM International, West Conshohocken, PA 2014, p. 13-22. DOI: 10.1520/ STP156920120201.

Ferguson J.C., Gaussoin R.E., Eastin J.A., Henry R.S., Kruger G.R. 2014b. Comparison of herbicide efficacy and adjuvants using a conventional sprayer and an ultra-low volume sprayer. Pesticide Formulation and Delivery Systems. Vol. 33. "Sustainability: Contributions from Formulation Technology". STP 1569, Carmine Sesa, ASTM International, West Conshohocken, PA 2014, p. 23-35. DOI: 10.1520/ STP156920120202.

Fidanza M. 2009. Fairy ring 101. USGA Green Section Record 47 (2): 8-10.

Fidanza M.A., Kaminski J.E., Agnew M.L., Shepard D. 2009. Evaluation of water droplet size and water-carrier volume on fungicide performance for anthracnose control on annual bluegrass. International Turfgrass Society Research Journal 11 (1): 195-205.

Gaussoin R., Schmid C., Frank K., Butler T., Liu H., Jarvis W., Baldwin C. 2009. Foliar uptake of nutrients applied in solution to creeping bentgrass (Agrostis palustris Huds.), annual bluegrass (Poa annua var. reptans (Hausskn.) Timm), and ultra-dwarf bermudagrass (Cynodon dactylon $\times$ C. transvaalensis Burtt-Davy). The Proceedings of the International Plant Nutrition Colloquium XVI. Available on: http://escholarship.org/uc/item/16j7j53q [Accessed: June 23, 2015]

Goss R.M., Baird J.H., Kelm S.L., Calhoun R.M. 2002. Trinexapacethyl and nitrogen effects on creeping bentgrass grown under reduced light conditions. Crop Science 42 (2): 472-479.

Hanks J.E., McWhorter C.G. 1991. Variable affecting the use of positive displacement pumps to apply herbicides in ultralow volume. Weed Technology 5 (1): 116-117.

Heckman N.L., Horst G.L., Gaussoin R.E., Frank K.W. 2001. Storage and handling characteristics of trinexapac-ethyl treated Kentucky bluegrass sod. Horticulture Science 36 (6): 1127-1130.

Johnson B.J. 1993a. Sequential herbicide treatments for large crabgrass (Digitaria sanguinalis) and goosegrass (Eleusine indica) control in bermudagrass (Cynodon dactylon) turf. Weed Technology 7 (3): 674-680.

Johnson B.J. 1993b. Differential large crabgrass control with herbicides in tall fescue and common bermudagrass. Horticulture Science 28 (10): 1015-1016.

Johnson B.J. 1997. Sequential application of preemergence and postemergence herbicides for large crabgrass (Digitaria sanguinalis) control in tall fescue (Festuca arundinacea) turf. Weed Technology 11 (4): 693-697.

Kramer C.Y. 1957. Extension of multiple range tests to group correlated adjusted means. Biometrics 13: 13-18. 
Kreuser W.C., Soldat D.J. 2012. Frequent trinexapac-ethyl applications reduce nitrogen requirements of creeping bentgrass golf putting greens. Crop Science 52 (3): 1348-1357.

Martin B. 2003. A new strobilurin fungicide for turfgrass disease control. Golf Course Management 71: 188-191.

Martin S.B., Lucas L.T. 1984. Characterization and pathogeniticity of Rhizoctonia spp. and binucleate Rhizoctonia-like fungi from turfgrasses in North Carolina. Phytopathology 74: $170-175$.

McCann S.E., Huang B. 2007. Effects of trinexapac-ethyl foliar application on creeping bentgrass responses to combined drought and heat stress. Crop Science 47 (5): 2121-2128.
McCullough P.E., Liu H., McCarty L.B., Toler J.B. 2007. Trinexapac-ethyl application regimens influence growth, quality, and performance of bermudagrass and creeping bentgrass putting greens. Crop Science 47 (5): 2138-2144.

Settle D., Fry J., Tisserat N. 2001. Dollar spot and brown patch fungicide management strategies in four bentgrass cultivars. Crop Science 41 (4): 1190-1197.

Stiegler J.C., Richardson M.D., Karcher D.E. 2011. Foliar nitrogen uptake following urea application to putting green turfgrass species. Crop Science 51 (3): 1253-1260. 